\title{
PLASTIC CONTRIBUTIONS FOR PENSIONS AND PROFIT-SHARING
}

\author{
ALVIN D. LURIE $\dagger$
}

THE number of companies adopting pension and profit-sharing plans grows apace. This growth would surely have been even greater were it not for the rigid contribution requirements to be met by "qualified" plans under the Internal Revenue Code. Qualification is the term applied in section 401 to plans entitled to the special tax benefits available under the Code: principally, exemption from income tax for trusts implementing such plans, ${ }^{1}$ and immediate deductibility of employers' contributions to the trusts ${ }^{2}$ coupled with deferred taxability of distributions to beneficiaries, the distributions even then sometimes being taxable only at capital gain rates. ${ }^{3}$ As guardian of these tax privileges, the Internal Revenue Service has assumed authority to dictate the very terms of these plans in the matter of contributions and, indeed, almost all the other diverse components of a plan, such as employees' eligibility and waiting periods, investments by the trust, vesting of participants' shares, retirement benefits and incidental insurance benefits, to name only a few. ${ }^{4}$ Nor does the Service's concern end with the adoption of the plan, for the workings of the plan in operation are also scrutinized.5 Cavalier observance of the contribution formula is a recurring cause of disqualification.

Against this background, the Treasury's sudden abandonment in 1956 of its long-standing requirement of a definite formula for profit contributions under qualified profit-sharing plans was an event of the first importance. ${ }^{6}$ For years, the Treasury had stood alone in insisting on a fixed contribution formula for qualified profit-sharing plans, while first the bar and then the judiciary railed against this stand. ${ }^{7}$ Only after Congress itself seemed pre-

† Member of the New York Bar.

1. INT. REv. CoDE of 1954, § 501 (a).

2. Id. $\S 404(\mathrm{a})$.

3. Id. $\$ 402(\mathrm{a})$. See also id. $\$ 403(\mathrm{a})$.

4. See Rev. Rul. 57-163, 1957 INT. Rev. BulL. No. 16, at 10 (collating the numerous rulings of the Internal Revenue Service covering every phase of pensions).

5. "The law is concerned not only with the form of the plan but also with its effects in operation. For example, section 401(a) (5) specifies certain provisions which of themselves are not discriminatory. However, this does not mean that a plan containing these provisions may not be discriminatory in actual operation." U.S. Treas. Reg. $\S 1.401-1$ (b) (3) (1956).

6. Compare the present provision, U.S. Treas. Reg. $\$ 1.401-1$ (b) (2) (1956), with U.S. Treas. Reg. 118, $\$ 39.165-1$ (a) (2) (1.939), as amended, T.D. 6189 , 1956-2 Cum. BuLL. 972.

7. See Lincoln Elec. Co. Employees' Profit-Sharing Trust v. Commissioner, 190 F.2d 326 (6th Cir. 1951), reversing 14 T.C. 598 (1950); McClintock-Trunkey Co. v. Commissioner, 217 F.2d 329 (9th Cir. 1954), reversing 19 T.C. 297 (1952); Produce 
pared to legislate the contribution formula out of existence in $1954,{ }^{8}$ did the Treasury yield.

Did this surrender presage a new freedom for employers in the fashioning of such plans and in the remodeling of plans from time to time after their adoption? Were pension plans now obsolete, or were contributions for pension plans also to be permitted the plasticity that now characterized profitsharing contributions? The Service's action, one might suppose, augured an era of profit-sharing plans without fixed profit-contribution formulas, with those profit-sharing plans already in existence promptly dropping their formulas.

An unofficial survey of several district directors' offices discloses that no such sweeping change has occurred in the pattern of pension and profitsharing plans. Several explanations may be suggested. First, of course, not all persons charged with the responsibility of overseeing the many pension and profit-sharing plans now in force have become familiar with the elimination of the formula requirement or appreciate its significance. Then, too, pension or profit-sharing plans which have become a part of the collectivebargaining structure cannot so easily be dropped or changed. ${ }^{9}$ Moreover, employee goodwill may be lost or injured if the formula is taken out of a plan.

For these obvious reasons, the status quo has been preserved. There are other reasons, perhaps not so obvious but far more fundamental, why pension plans and profit plans incorporating a formula will continue as important factors in deferred-compensation planning. The assumption is generally made that employers would be anxious, at all costs, to avoid the fixed obligation imposed by formula. But flexibility of the employer's contribution obligation is not always the predominant consideration in choosing between a pension and profit-sharing plan. Again, the supposed rigid contribution requirements of a pension plan are not as inflexible as has been pictured. Furthermore, the bar will come to realize that at least as many drawbacks as advantages may attend the elimination of the fixed formula from a profitsharing plan. Finally, in a number of other ways under either a pension or profit-sharing plan, the desired plasticity of contribution may be attained without the drawbacks of a plan lacking a formula.

\section{Choosing Between Pensions and Profit-Sharing}

The matter of contributions is certainly a major factor in the choice between pension and profit-sharing plans, but there are others. First, a funda-

Reporter Co., 18 T.C. 69 (1952), aff'd, 207 F.2d 586 (7th Cir. 1953) ; E. R. Wagner Mfg. Co., 18 T.C. 657 (1952).

8. The house bill for the 1954 Code would have expressly barred the absence of a contribution formula as a basis for disqualification. H.R. 8300, 83d Cong., 2d Sess. § 501 (e) (1954) ; H.R. REP. No. 1337, 83d Cong., 2d Sess. a168 (1954).

9. See Gordon, Integrating Union and Non-Union Pension Plans, N.Y.U. 15тн INST. ON FED. TAX. 1147, 1148 (1957). 
mental difference in philosophy exists between the two: a pension plan is designed "to provide systematically for the payment of definitely determinable benefits ... after retirement" $;^{10}$ a profit-sharing plan, on the other hand, provides "for participation in ... profits . . . after a fixed number of years, the attainment of a stated age, or upon the prior occurrence of some event," not necessarily retirement. ${ }^{11}$ Employers' attitudes obviously differ on whether their employees are more responsive to the security of definitely determinable retirement benefits in a pension plan or to the entrepreneurial drive that comes of sharing in current profits. Actually, each employee's share of profits in any year normally can be no more than $15 \%$ of his compensation for that year - at least, the employer cannot deduct a contribution in a greater amount. ${ }^{12}$ Nevertheless, a profit-sharing plan may provide that the funds forfeited by any employees leaving the company before their benefits mature shall be reallocated among the remaining employees $;^{\mathbf{1 3}}$ in this way, the real shares of profits for long-standing employees can be significant indeed. On the other hand, forfeitures cannot be reallocated in a pension plan; to do so would defeat the pattern of definitely determinable benefits, the essence of such a plan. ${ }^{14}$

Nevertheless, the choice between a pension plan and a profit-sharing plan is only rarely predicated on a preference by the employer for its employees' retirement security over their participation in profits, or vice versa. Also of relatively minor importance in the choice between pensions and profit-sharing is the desire to provide retirement benefits, as distinguished from deferred benefits realizable before retirement, since the bulk of profit-sharing plans are of the retirement type; they differ from pension plans mainly in the basis for making contributions and in the lack of certainty of the amount of the retirement benefit.

A far more important consideration in the employer's choice is the ease of giving recognition to an employee's length of service in a pension planeven service in years before the plan was established. The Service has approved, with limitations, profit-sharing plans containing a length-of-service factor that gives credit in the allocation of contributions not only for relative compensation of participants but also for relative length of employment. ${ }^{15}$ But in a profit-sharing plan, any such formula is likely to discriminate in favor of highly compensated employees, and attempts to devise a profit-sharing plan where recognition of past service is the primary object have generally been discouraged. On the other hand, in pension plans it is normal to provide for a pension equal, for example, to $1 \%$ of compensation

10. U.S. Treas. Reg. $\$ 1.401-1$ (b) (1) (i) (1956).

11. U.S. Treas. Reg. $\$ \$ 1.401-1$ (a) (2) (ii), (b) (1) (ii) (1956).

12. Int. Rev. Cone of 1954, § 404(a) (3) (A).

13. Rev. Rul. 57-163, 1957 INT. Rev. Bull. No. 16, at 28.

14. U.S. Treas. Reg. $\$ 1.401-1$ (b) (1) (i) (1956).

15. I.T. 3685, 1944 Cuar. Bull. 324; see Rev. Rul. 57-163, 1957 Int. Rev. Bull. No. 16, at 28; cf. I.T. 3686, 1944 CuM. Bull. 326. 
for each year of employment before the plan began and $1 \frac{1}{4} \%$ for each year of employment after. This has obvious appeal where the employer's stockholders or other key employees have the most service before the plan's commencement.

Some pension plans provide simply for a fixed retirement benefit regardless of the number of years of employment-for example, $35 \%$ of the average compensation for the last five years. Where the employer's stockholderemployees or other highly regarded employees are within a relatively few years of retirement when the plan is begun, they can be given a full pension at retirement, just as if the plan had been in force during all their working years. Nothing comparable can be achieved with a profit-sharing plan.

Doubtless, the choice of a pension plan or a profit-sharing plan for the typical employer is made by its attitude towards the basis for fixing contributions. In pension plans, the actuary's handbook controls; in profit-sharing, the accountant's profit and loss statement is determinative. Pension plans impose a more-or-less fixed commitment on the employer to contribute the amount actuarially determined as necessary to provide the benefits after retirement. In a plan funded by individual insurance company contracts for each employee, the employer's contribution is the aggregate of the fixed insurance premiums. In a self-insured plan, the actuary's computation from year to year measures the contribution; but this too is fixed, for it depends on actuarial assumptions rather than the employer's whim or ability to pay.

In a profit-sharing plan, however, the contribution is tied only to the availability of profits, even where the plan has a fixed-contribution formula. For example, the plan might provide for a contribution of $10 \%$ of the year's profits, to be divided ratably among all employee participants. The employer knows that it will have no obligation under the plan if there are no profits. For this reason, many small companies prefer profit-sharing to pensions; they feel more comfortable about committing themselves to put even as much as $50 \%$ of their profits into the retirement fund than about guaranteeing perhaps less than half of this amount to a pension plan when there are no profits.

\section{Flexibility of Pension Contributions}

This element of guaranteed contributions is inherent in pension plans because of the promise of the plan to provide "definitely determinable benefits after retirement." Thus, the employer assumes a definite contractual obligation to the plan's trustees to contribute enough over the years to fulfill this promise; and the Internal Revenue Code tends to compel spreading the cost of a plan fairly evenly from year to year. While not actually prescribing a set pattern of contributions, the Code permits deductibility of contributions only on a more-or-less constant basis.

However, the commitment for a pension plan need not be as inflexible as is sometimes supposed. The Code recognizes two competing actuarial approaches to the funding of pension plans. Under either, an employer's con- 
tributions are deductible. One, level funding of past and current service, involves the distribution of the remaining cost of past and current service credits as a level amount, or level percentage of compensation, over the remaining future years of service of the employees. ${ }^{16}$ The other, normal cost and accelerated funding of past service, requires a contribution to be made for what would be the current year's cost if the plan had been in force from the earliest year of credited past service, called the "normal cost," to which may be added not more than $10 \%$ of the actuarial deficiency, which is the cost of all the unfunded past service and other benefits. ${ }^{17}$

A considerable range of sums, however, might constitute the contribution for any year, not only as between these two methods but under either of them, because of the numerous delicate actuarial decisions that go into the determination of any year's contribution. ${ }^{18}$ Certain funding assumptions might permit a corporation to get ahead on its contributions in highly profitable years or, conversely, to coast in lean years.

These opportunities for maneuverability by the employer exist, in the main, where the plan is self-funded. If it is funded by annuity contracts with an insurance company, the required contribution will generally be a constant amount equaling the annual premiums, except for the effect of borrowings against policy cash values to meet premiums. However, most insurance companies have available a side-funding program, under which the policies issued are ordinary or other forms of life insurance rather than retirement income policies. The only amounts paid to the insurer are premiums on the life insurance policies; but the insurer at the same time advises the trustees of the additional amount which the employer must contribute to a side fund in order to convert the life insurance policies into annuities at the retirement of participants then employed. Flexibility enters in the calculation of the side fund. Moreover, where the plan is funded by separating the "normal costs" and the costs for past service, the side-fund contribution goes both towards the future service liability and the past service liability; and therefore the side-fund contribution can be shaded as financial circumstances dictate, because, as noted below, past service costs need not be met at a time when the unfunded past service liability is no greater than it was at the date of establishment of the plan.

Another type of pension plan that permits employers some degree of control over contributions is the money-purchase plan, under which the employer's annual contribution is a fixed amount or fixed percentage of each employee's compensation, and the retirement benefit is equal to whatever amount can be purchased with the fund accumulated for the benefit of each employee. ${ }^{19}$ In this type of plan, therefore, the contribution is fixed rather than the benefit. The employer is thus able to project its funding obligation

16. INT. Rev. CoDE of 1954, $\$ 404$ (a) (1) (B).

17. Id. $\$ 404$ (a) (1) (C).

18. See, c.g., Saalfield Publishing Co., 11 T.C. 756 (1948); Philadelphia Suburban Transp. Co. v. Smith, 105 F. Supp. 650 (E.D. Pa. 1952).

19. See Mim. 6641, 1951-1 Cuxr. Bull. 41, 50. 
quite definitely, instead of committing itself to contribute whatever amount may be determined actuarially to be necessary to provide a fixed retirement benefit.

\section{Integration With Social Security}

The burden of the employer's commitment in a pension plan can be considerably lightened, without any substantial sacrifice of advantages for the employee, where the benefits under the plan are integrated with the benefits provided by the Social Security Act. ${ }^{20}$ A plan is deemed integrated when the benefits under the plan are proportionate to the benefits under the Social Security Act. For this purpose, the Service has developed the assumption that the social security benefits may be expressed as equivalent to a retirement pension of $37 \mathrm{x} / 2 \%$ of the first $\$ 4,200$ of compensation. ${ }^{21}$ Accordingly, a so-called $\$ 4,200$-excess plan-one which excludes all employees earning less than $\$ 4,200$ and all compensation below $\$ 4,200$-will be integrated with social security if the assumed retirement pension does not exceed $37 \% / 2 \%$ of compensation in excess of $\$ 4,200$. Downward adjustment of the benefit rate is required if the plan provides death benefits, survivorship annuity rights or other special features. In lieu of excluding compensation below $\$ 4,200$, any figure above or below that sum can be used, although the benefit rate would then have to be adjusted accordingly; or, a lower benefit rate can be applied to compensation below $\$ 4,200$ and a higher rate to compensation above $\$ 4,200$. Moreover, instead of a flat benefit rate, benefits may be related to years of service-for example, $1 \%$ on the first $\$ 4,200$ of compensation and $2 \%$ on all compensation over that for each year of coverage. Money-purchase plans may also be integrated, provided the employer's contributions do not exceed one fourth of the normal benefit rate allowed on compensation over $\$ 4,200$ for an integrated straight-life annuity plan. ${ }^{22}$ Thus, assuming that the employer would be permitted to establish the maximum benefit rate$371 / 2 \%$ - he may make a contribution equal to one fourth of that rate, or $93 / 8 \%$, on compensation over $\$ 4,200$.

Profit-sharing plans can also be integrated with social security, although it may seem anomalous to attempt to integrate the variable and uncertain benefits of a profit-sharing plan with the predictable benefits of the Social Security Act. The basis for integration is the same as for a money-purchase pension plan: in a $\$ 4,200$-excess plan, a maximum contribution rate of $93 \% \%$ of compensation in excess of $\$ 4,200 .^{23}$ If forfeitures are reallocated to par-

20. The basic rules for integrating a pension plan are set forth in U.S. Treas. Reg. $\$ 1.401-3$ (e) (1956). Detailed requirements appear in Mim. 6641, 1951-1 Cunr. Buls. 41, as amended, Rev. Rul. 13, 1953-1 Cum. Bull. 294; Mim. 5539, 1943 Cun. Bulz. 499. See Goldstein, Integrating Pension and Profit-Sharing Plans With Social Security, N.Y.U. 15TH INST. ON FED. TAX. 1165 (1957).

21. U.S. Treas. Reg. $\$ 1.401-3$ (e) (1.956).

22. Ibid.

23. U.S. Treas. Reg. $\S 1.401-3(\mathrm{e})(2)$ (1956) ; Mim. 6641, 1951-1 Com. Bull. 41. 
ticipants, however, the employer contribution taken together with forfeitures may not exceed this maximum rate. An integrated profit-sharing plan qualifies under the Service's rules only if the plan provides benefits solely on retirement or separation from service and the employer does not also maintain an integrated pension plan for the same employees.

Integration affords the employer considerable relief in that it sharply contracts the contribution base (either in a pension plan or a profit-sharing plan) to the prejudice of the lower-paid employees but without any significant effect upon the more highly compensated employees. An employer with an integrated plan may legitimately deduct contributions currently and at the same time offer, to those with highly paid managerial skills whom he desires to attract or retain, the benefits of secured retirement income, with taxation deferred to lower income years, possibly at capital gain rates. ${ }^{24}$ And within these limits, an integrated plan is not regarded as discriminatory, since the benefits under it, in theory at least, merely extend to compensation not covered by social security the same proportionate benefits as obtain for covered compensation.

\section{Suspending Contributions}

Relief from the burden of contributions can be achieved in still another way: in a loss year, or even when profits are off or money is scarce, the employer may temporarily suspend contributions to the plan. An employer should never undertake such a step lightly, because the suspension can cause retroactive disqualification of the plan if it is regarded as indicative, from the very inception, of a lack of intention to establish a bona fide permanent plan for the exclusive benefit of employees in general $;^{25}$ or, the suspension of contributions may be regarded as tantamount to a termination of the plan, with the result that funds of the plan must be distributed 26 -although not necessarily at once so long as the plan of distribution does not discriminate in favor of officers, shareholders, supervisors or highly compensated employees. ${ }^{27}$

Temporary cessation of contributions, however, need not have either of these serious consequences. In a pension plan, the temporary suspension of contributions can be without any consequences so long as the benefits under the plan are not affected by the suspension and, if the plan provides benefits for persons employed prior to its inception, the remaining unfunded past service cost does not exceed the cost of such past service which was unfunded

24. Compare the treatment of nonqualified annuities, INT. REv. Cone of 1954, $\$ 403$ (b) (amount contributed by employer for nonqualified annuities, to which the employee's rights are nonforfeitable, immediately taxable to employee). Cf. United States v. Drescher, 179 F.2d 863 (2d Cir. 1950).

25. U.S. Treas. Reg. $\S 1.401-1$ (b) (2) (1956).

26. Rev. Rul. 57-163, 1957 Int. Rev. Buli. No. 16, at 30.

27. Id. at $29-30$. 
at the time of establishment of the plan. ${ }^{28}$ This normally means that, in so far as past service cost is concerned, payment of an amount equal to interest on the unfunded cost is sufficient.

A temporary suspension of contributions to a profit-sharing plan, however. is more serious. No rule-of-thumb test will assure continued qualification of the plan. It is essential to advise the District Director of Internal Revenue of the suspension and to request a redetermination regarding the qualification of the plan. ${ }^{29}$ Revenue agents tend to look askance at the suspending of contributions to a profit-sharing plan. Failure to conform to the plan can occur only when the employer has the profits requisite for the contribution: for absent profits, the failure to make the contribution would not be a suspension. From the employer's viewpoint, however, the existence of profits is not always the same as the availability of cash with which to make a contribution. While one court has held that the contribution may be made in the form of a negotiable promissory note, ${ }^{30}$ even the issuance of such a note may at times be embarrassing to a company from a credit standpoint. In such circumstances, where the suspension of contributions is obviously dictated by business exigencies, a favorable determination. of continued qualification of the plan can probably be secured from the local director's office.

Nevertheless, it might be advisable to include in profit-sharing plans a provision for full vesting of participants' shares upon the occasion of the suspension of contributions. The Treasury's rules require full vesting upon a "discontinuance" of contributions, since vesting is necessary at the termination of a plan and the discontinuance of contributions is held to be in effect an informal termination. ${ }^{31}$ A mere temporary "suspension" of contributions to a profit-sharing plan which has not ripened into a "discontinuance" would not seem to be an informal termination; but the Internal Revenue Service has specifically exempted from the "full vesting" requirement only suspensions of contributions to pension plans, ${ }^{32}$ leaving ambiguous the requirement as to vesting in case of suspending contributions to a profitsharing plan.

\section{Profit-Sharing Witerout Fordiula}

The rules regarding the effect of suspending contributions to a profit-sharing plan were developed while the Treasury still adhered to its requirement that qualified plans contain a formula for fixing each year's contribution of profits. In the Regulations under the 1954 Code, the Treasury dropped the requirement. ${ }^{33}$ The paradox today is apparent: the temporary suspension of

28. Id. at 30; Rev. Rul. 56-596, 1956-2 CuM. Bulr. 288.

29. Rev. Rul. 55-480, 1955-2 Cum. Burl. 227; P.S. No. 57 (Aug. 5, 1946).

30. Sachs v. Commissioner, 208 F.2d 313 (3d Cir. 1953). But see Rev. Rul. 55-608, 1955-2 Cunr. Bull. 546.

31. Rev. Rul. 55-186, 1955-1 Cun. Bull. 39; Rev. Rul. 56-596, 1956-2 Cun. Bull. 288.

32. Ibid. See also Rev. Rul. 57-163, 1957 INT. Rev. Bull. No. 16, at 30.

33. See note 6 supra. 
the contributions required under the formula of a profit-sharing plan may cause its loss of qualification or may precipitate full vesting and in any event requires the submission of a request for redetermination of qualification; but a profit-sharing plan which qualifies without a contribution formula contains, on the surface, no such hazards in the event of the failure to make a contribution in any particular year.

Perhaps, the Treasury's abandonment of the formula requirement cannot be taken at face value and may yet prove to be not unlike Greeks bearing gifts. Until very recently, the Treasury tenaciously insisted a contribution formula was necessary to comply with its requirements for a "permanent" nondiscriminatory plan. ${ }^{34}$ To the Treasury, "permanent" meant recurring contributions. Although surrendering on the formula issue, the Treasury's Regulations still call for a "permanent" plan and cite abandonment of the plan, as by the mere making of "a single or occasional contribution out of profits," as evidence that the plan was not a bona fide program for the exclusive benefit of employees. ${ }^{35}$ The case that first gave impetus to the movement for abolition of the fixed-formula requirement was the famous Lincoln Electric Company decision, which held that a single contribution was adequate for a qualified plan. ${ }^{36}$ Clearly, the Treasury has not embraced the principle of that case.

The Regulations expressly concede that "it is not necessary that the employer contribute every year" or contribute the same amount, or in accordance with the same ratio from year to year; but "recurring and substantial contributions out of profits" are required. ${ }^{37}$ Moreover, the Regulations warn that a plan does not qualify, whether or not it contains a formula for profits, "if the contributions to the plan are made at such times or in such amounts that the plan in operation discriminates" in favor of officers, stockholders, and so forth. ${ }^{38}$

Therefore, the execution of a plan without a profit formula at the very least stamps the plan as potentially vulnerable and may actually carry the seed of the plan's own destruction. An employer whose formula plan has been approved by the Director is reasonably assured that if it adheres to the formula the plan will continue qualified. But no such certainty of tax status can ever attach to a plan without a formula. No standard has been put forward by the Treasury against which the occurrence of a "suspension" can be measured. The reduction of contributions in a particular year may be regarded as discriminatory. And the failure to make any contribution may raise the question of permanency.

34. Ibid.

35. U.S. Treas. Reg. $§ 1.401-1$ (b) (2) (1956).

36. Lincoln Elec. Co. Employees' Profit-Sharing Trust v. Commissioner, 1.90 F.2d 326 (6th Cir. 1951).

37. U.S. Treas. Reg. § 1.401-1(b) (2) (1956).

38. U.S. Treas. Reg. $\S 1.401-1$ (b) (1) (1956). 
The absence of a formula, apart from creating uncertainty, actually encourages abuse, for it may lull the employer into the assumption that any pattern of contributions is permissible. An employer desiring some latitude for contributions is better advised to provide a minimum and maximum contribution-for example, "not less than five per cent nor more than fifteen per cent of profits, as the directors shall decide from year to year."

One other undesirable feature of a no-formula plan is the burden it imposes of establishing affirmatively the liability of the employer for each year's contribution before the end of the tax year, presumably by a director's resolution fixing either the amount of the contribution or the method of determining it. ${ }^{39}$ The exact dollar amount of the contribution need not be fixed, but the formula for determining this amount must certainly be set before the year's end. In the absence of satisfactory evidence that this has been done, the contribution will not be deductible in a given year if not paid before the end of that year, under the general principles governing the deductibility of expenses on the accrual basis. ${ }^{40}$ Conversely, a plan containing a definite formula itself establishes the liability each year, ${ }^{41}$ and nothing more is required than the making of the contribution no later than the last day for filing that year's tax return. ${ }^{42}$

\section{Make-UP Contributions}

Where contributions have been suspended for a time under a profit-sharing plan containing a profit formula, or where the contribution made is less than that called for under the formula, apparently the employer may in some cases make up the passed contribution in a succeeding year and take a deduction for the extra contribution in that later year. ${ }^{43}$ The amount of make-up contribution that can be deducted in any subsequent year is limited to the amount, if any, by which the contribution in the year of suspension fell below $15 \%$ of the compensation of all employees under the plan in the suspension year, and is further limited to $15 \%$ of the compensation of all employees under the plan in the year of make-up. This latter limitation applies only to the make-up contribution; an additional deduction up to $15 \%$ of compensation is allowable for the current contribution of the later year.

39. See Rev. Rul. 56-366, 1956-2 Cum. Bull. 976.

40. U.S. Treas. Reg. \$ 1.404(a)-1.(c) (1956). See Barrett Timber and Dunnage Corp., 29 T.C. No. 11 (Oct. 18, 1957) (showing the extent to which the tax court will hold a corporation to strict compliance with accrual rules).

41. See note 39 supra.

42. See INT. Rev. Code of 1954, § 404(a) (6).

43. See id. $\$ 404$ (a) (3) (A). Clearly, where the formula provides for a contribution which is less than $15 \%$ of the compensation of covered employees, the make-up contribution is proper under the statute. The question is whether a voluntary contribution deficiency, caused by the failure to contribute as much as the formula requires, creates a carry-over credit which can be made up in a subsequent year. The plain words of the statute indicate that the prior year's contribution gives rise to a carry-over credit simply if it is less than the maximum allowed as a deduction, i.e., $15 \%$ of the compensation of covered employees. 
Presumably, the plan itself need contain no provision for a make-up contribution. The mere volunteering of a contribution in excess of the requirements of the plan is no longer fatal to deduction, now that the fixed-formula requirement has been dropped. ${ }^{44}$ Thus, if the plan simply requires a contribution of the lesser of $10 \%$ of profits or $15 \%$ of compensation, and the latter limitation equals $\$ 20,000$ while the former equals $\$ 15,000$, an employer who in a previous year failed to make a $\$ 5,000$ contribution despite the necessary profits can make up the suspended contribution in the later year by contributing the full $\$ 20,000$, even though his plan required no make-up contribution. In fact, even more than $\$ 20,000$ may be contributed, because the make-up contribution alone can equal $\$ 20,000$.

Where a profit-sharing plan does not contain a formula for contributions, an employer seemingly can make no contribution in one year and then contribute and deduct as much as $30 \%$ of the compensation of covered employees in a later year-twice the deduction that is ordinarily allowable for contributions to profit-sharing plans. Of course, contribution to a plan containing no formula cannot be regarded as a make-up contribution. But the Code does not speak in terms of a make-up: it permits the extra deduction in a later year whenever in an earlier year "there is paid into the trust ... amounts less than the amounts deductible" for the earlier year-amounts less than $15 \%$ of the regular compensation paid to employees in such earlier year.

\section{Excessive Contributions}

The converse of a passed contribution is an excessive contribution, a contribution in excess of what is deductible in a given year. An employer anticipating fluctuating profits from year to year may nevertheless want to average out the contributions for its employees. If it were to limit its contributions to the smaller of $10 \%$ of profits or $15 \%$ of compensation, for example, the contributions in low-profit years could well be below $15 \%$ of compensation, with no opportunity to make them up in high-profit years. But if the formula called for a fixed contribution of $10 \%$ of profits, whether or not this figure was in excess of the deductible limit of $15 \%$ of compensation, a high-profit contribution could make up for low years. The statute permits a carry-over of the excessive contribution, for deduction purposes, into a later year when and to the extent that the current contribution in the later year is less than $15 \%$ of compensation. ${ }^{45}$ This type of deduction for excessive contributions of prior years is generally called a "contribution carry-over"; it differs from the extra deduction permissible when an additional contribution is made in a later year to make up for a passed contribution of an earlier year, known as a "credit carry-over," in that the contribution carryover deduction together with the current deduction is limited to $15 \%$ of the current year's compensation, while a credit carry-over is itself deductible up to the amount of $15 \%$ of the current year's compensation.

44. Rev. Rul. 56-366, 1956-2 CuM. BulL 976.

45. INT. REv. CODE OF 1954, \& 404(a) (3) (A). 
Consistent with its requirement of contributions pursuant to a definite formula, the Service formerly permitted a contribution carry-over deduction only when the excessive contribution of the earlier year was required under the terms of the plan. Thus, a contribution equal to $15 \%$ of compensation, under a plan calling for the lesser of $10 \%$ of profits or $15 \%$ of compensation, in a year when the profit limitation was less than $15 \%$ of compensation, was ruled ineligible for carry-over. ${ }^{46}$ This ruling no longer applies. ${ }^{47}$ An employer is now free to ignore the formula contained in its profit plan and contribute in excess of what is required. The excess will be currently deductible to the extent that the total contribution for the year does not exceed $15 \%$ of compensation or will be deductible as a carry-over in succeeding years.

\section{Make-Ups by Affiliated Companies}

A different kind of make-up contribution can be effected where a profitsharing plan has been adopted by a group of affiliated corporations-corporations connected to each other and to a common parent corporation through ownership in each case of at least $80 \%$ of the stock. If the plan calls for contributions of $15 \%$ of the compensation of covered employees out of earnings and profits, and all employers of the group but one have the necessary earnings and profits to cover the contribution, the profitable employers may contribute and deduct for tax purposes the amount which the deficient corporation was prevented from contributing because of lack of earnings. ${ }^{48}$ However, the contribution by the other corporations may only be made out of their earnings or profits, current or accumulated, and may not exceed that portion of each such corporation's earnings which the prevented contribution bears to the total earnings of all members of the group. The mere fact that one of the companies has no current profits does not justify a contribution on its behalf by its affiliates so long as it has accumulated earnings.

To take advantage of this technique, all member corporations of the group which desire to participate in the plan must adopt a single plan ;0 $^{40}$ and the plan should provide expressly for make-up contributions by affiliates where any member of the group does not have the requisite current or accumulated earnings for its contribution. However, the statute does not require any express provision; and if the volunteering of extra contributions is now permissible under a single-company plan, ${ }^{50}$ it would appear equally permissible under plans of affiliated companies.

46. I.T. 4055, 1951-2 CuM. Buli. 30.

47. Rev. Rul. 56-366, 1956-2 Cum. BuLL. 976.

48. INT. REv. CoDE OF 1954, § 404(a) (3) (B).

49. U.S. Treas. Reg. $\$ 1.404$ (a)-(10) (a) (1) (1956).

50. Rev. Rul. 56-366, 1956-2 Cum. BuLl. 976. 


\section{Profit-Sharing Without Profits}

The statutory provisions dealing with plans for affiliated companies seem to resolve a long-standing doubt as to whether deductible contributions can be made to a profit-sharing plan in a year when there are no current profits but ample accumulated earnings exist to cover the contribution. The Code does not define a profit-sharing plan, and the Regulations state only that it is a plan established to enable employees "to participate in the profits of the employer's trade or business." tained language designed explicitly to authorize contributions in excess of current earnings but not more than accumulated earnings 52 _"as under existing law," according to the House report. ${ }^{53}$ While this along with almost all the other House provisions relating to pensions and profit-sharing failed of enactment "pending further study," the implication of the "affiliated company" provision, which was enacted and which permits contributions by related companies "to the extent of current or accumulated earnings or profits" when one of the companies has "no current or accumulated earnings or profits," $"$ is clear.

\section{Amendments to Plans}

When a plan is no longer suited to an employer's needs, it can be amended. However, an amendment involving a reduction of benefits may be regarded as a curtailment or partial termination, ${ }^{56}$ resulting in discrimination and causing loss of qualification. The business necessity of reducing contributions to the plan would obviously be relevant. In any event, the proposed amendment should be submitted to the Service for approval of the continued qualification of the plan in its amended form. ${ }^{57}$

Even where an employer desires to increase benefits under the plan, a formal amendment is advisable. In one case, however, where the tax court held that the contribution of profits in excess of those required under the profit formula in the plan was voluntary and hence nondeductible, ${ }^{58}$ it was reversed by the circuit court which held that the contribution in such circumstances constituted an effective informal amendment. 59 The Service has since adopted the view of the circuit court. ${ }^{60}$

Where a plan containing a profit formula has already been approved, an amendment of the plan which has the sole purpose of eliminating the for-

51. U.S. Treas. Reg. $\S 1.401-1$ (a) (2) (ii) (1.956).

52. See H.R. 8300, 83d Cong., 2d Sess. $\S 501$ (e) (1954).

53. See H.R. REp. No. 1337, 83d Cong., 2d Sess. a168 (1954).

54. 'See S. ReP. No. 1622, 83d Cong., 2d Sess. 53-54 (1954).

55. INT. REv. CoDE OF 1954, § 404(a) (3) (B).

56. Mim. 6136, 1947-1 Cum. Bulz. 58.

57. See Rev. Proc. 56-12, 1956-1 CuM. Buld. 1029, for procedure relating to advance determinations regarding amendments.

58. McClintock-Trunkey Co., 19 T.C. 297 (1952).

59. McClintock-Trunkey Co. v. Commissioner, 217 F.2d 329 (9th Cir. 1954).

60. Rev. Rul. 56-366, 1956-2 Cuar. Bull. 976. 
mula need not be submitted to the Service for approval. ${ }^{61}$ Amendments made at any time during a year, retroactive to the beginning of such year, will be effective for the entire year. ${ }^{62}$

\section{Conversion of Pension Plan Into Profit-Sharing Plan}

The most drastic kind of amendment that could be made to a pension plan would be its transformation into a profit-sharing plan. The changing business conditions affecting a company, or the changed composition of its personnel, may sometimes bring about a situation requiring the replacement of the company's pension plan with a profit-sharing plan. Of course, the pension trust could be completely terminated and a new profit-sharing trust formed. However, such a step presents several hazards. First, the Service might deem termination of the trust indicative of a lack of good faith in the initiation of the pension plan in the first instance, with resulting retroactive disqualification. Again, the vesting and distribution of credits built up in the pension trust might be regarded as discriminatory in favor of the stockholder-employees and other highly compensated personnel. Third, the termination of the plan might force upon participants a realization of their benefits at ordinary income rates, thereby depriving them of the very considerable advantage of reporting these benefits as capital gain, as they could where the distribution of benefits in a lump sum occurred in connection with severance of employment.

The solution naturally suggested is the simple transformation of the pension trust into a profit-sharing trust by amendment, thus avoiding some or all of these consequences. As a matter of trust law, no objection seems to arise so long as the vested interests of participants are not impaired. As a matter of tax law, on the other hand, the transaction would probably be .viewed as a termination, or at least a curtailment, of the pension plan. ${ }^{33}$ Thus, this technique does not preclude inquiry into the employer's action as reflecting unfavorably on its good faith in instituting the pension plan originally. But since an amendment of the trust, even one changing the basic nature of the underlying plan, does not amount to a termination at law, the transformation of the trust into a profit-sharing plan would not seem to make the termination clause of the trust operative; thus no employee would become entitled to distribution or to accelerated vesting, as would normally occur on the occasion of an actual termination of the trust. Nevertheless, the questions remain whether the mere application of a member's pension credits toward his account in the profit-sharing plan may itself be inherently discriminatory and, in any event, whether such an application or transfer of

61. Rev. Proc. 56-22, 1956-2 CuM. Bull. 1380.

62. P.S. No. 35 (rev. Nov. 16, 1944).

63. See Mim. 6136, 1947-1 Cun. Bulz. 58; P.S. No. 57 (Aug. 5, 1946). See also Address by Isidore Goodman, Chief, Pension Trust Branch, Tax Rulings Division, P-H Pens. \& Profit-Shar. Serv. If 1029 (1953). 
credits from a member's account under the one plan to the other involves a constructive realization of income, quite the same for tax purposes as if the benefits were actually distributed.

The pouring of pension credits into a profit-sharing plan usually cannot be accomplished without some inequity among employees. Credits build up in participants' accounts under a pension plan on a completely different basis from that of a profit-sharing plan. In a typical pension plan, contributions are allocated to participants' accounts in accordance with actuarial calculations of the amounts necessary to fund each participant's planned retirement benefit, based on his age, salary or other governing factors. Thus, an older employee, who has served fewer years or is earning less salary than a younger employee, may nevertheless have credits many times greater than the younger employee. In a profit-sharing plan, on the other hand, the credits of participants generally represent simply the aggregate of each year's profits division and are generally proportionate to salary.

Obviously, then, the mere transfer of members' credits from a pension plan to a profit-sharing plan is potentially discriminatory in favor of officers, shareholders, and supervisory and other highly compensated employees, since these favored categories are likely to comprise the older employees whose pension accounts will have grown disproportionately to their relative salaries. The law requires that either the contributions to or the benefits under the plan shall not discriminate to the advantage of the favored categories of employees. ${ }^{04}$ In a pension plan, the contributions will almost certainly so discriminate, but since the benefits generally "bear a uniform relationship" to salary, ${ }^{65}$ the prohibited discrimination is avoided. ${ }^{60}$ Conversely, under a profit-sharing plan, the contributions are customarily proportionate to salary so that the "nondiscrinination" rule need not be satisfied as to benefits. But where a pension plan is transformed into a profit-sharing plan, the discriminatory features of both are combined, the employee's benefits under the profitsharing plan being directly related to the discriminatory contributions provided for him under the pension plan.

Some means must therefore be devised for limiting the benefits which may be enjoyed under the profit-sharing plan to those that would have been enjoyed had the pension plan been continued. The "twenty-five highest paid employees" clause, found in all pension plans which have secured the approval of the Service, would seem the instrument for accomplishing this aim. ${ }^{67}$ This

64. INT. REv. CODE OF 1954, \& 401(a) (4).

65. See id. \$ 401 (a) (5).

66. See Address by Isidore Goodman, supra note 63 .

67. See Mim. 5717, 1944 Cum. Bull. 321 ; P.S. No. 42 (Nov. 11, 1944). However, the Service has taken the position that there is "no practical device, similar to Memeograph 5717 [sic] ... to correct discrimination in event of early termination or discontinuance of contributions" to a profit-sharing plan. Rev. Rul. 57-77, 1957 INT. REv. BuLl. No. 9, at 16. The ruling involved a "profit-sharing" plan under which contributions were required to be allocated among participants so as to provide retirement benefits 
clause provides a limitation on benefits, for employees whose benefits would exceed $\$ 1,500$ annually, to those purchasable for $\$ 20,000$, although a greater sum, up to $\$ 100,000$, is allowed for employees earning salaries of $\$ 50,000$ and over. This limitation need only be operative during the first ten years of the plan's existence. On the occasion of the conversion of the pension plan into a profit-sharing plan, this limitation may be satisfied in two ways: provision may be made for the immediate reallocation to all other employees' accounts of the amounts in excess of $\$ 20,000$-or other higher sum if applicable to the plan-in each of the highest paid employees' accounts; or the limitation on benefits that would have obtained had the pension plan continued may be made applicable to benefits available under the profit-sharing plan until a certain date not less than ten years after the original inception of the pension plan.

This discussion principally concerns situations in which the pension plan which preceded the profit-sharing plan provided fixed benefits for all employees at retirement-for instance, a monthly pension of $35 \%$ of the member's salary at the time of retirement. Where a unit-benefit pension plan is in effect-a plan providing for a retirement pension equal to some percentage of the employee's earnings, for example, $11 / 2 \%$ for each year of service while the plan is in existence-the disproportionate build-up of credits in favor of older persons does not exist. However, even in a unit-benefit plan, if pastservice credits are provided, like a pension of $1 \%$ of salary for each year of service before the pension plan was started, the problem of potential discrimination again arises and presumably must be obviated by one of the suggested methods.

So far, only the case of a pension plan which is changed into a profit-sharing plan has been considered, but the converse is just as likely. The same opportunity for discrimination does not appear where a profit-sharing plan is made over into a pension plan. In this situation, the profit-sharing credits may in some instances be converted into past-service credits under the pension plan for years of service prior to the change-over. If no suitable use can be made of the profit-sharing credits as part of the pension program, these credits could, of course, be distributed, but this course would thrust upon the participants a taxable realization of their benefits.

Even if no distribution takes place, another problem, already suggested, must be considered. Without actual distribution, participants may nonetheless be saddled with taxable realization of their benefits at the time a pension plan is remade into a profit-sharing plan, or vice versa. The Service might argue that the remodeling amounts to a constructive realization. If, as has been assumed, the amendment of a pension trust to make it into a profitsharing plan does not legally amount to a termination of the trust and does

proportionate to compensation, taking into account age and sex differences-in other words, a hybrid pension and profit-sharing plan. The Service declined to give an advance ruling as to qualification, because of the possibility that such a plan in operation may fail to qualify in certain years. 
not entitle the participants to receive immediate distribution of their vested interests, it does not seem that constructive realization can be found. Suppose, however, that participants' accounts are fully vested at the time of change, either because the amendment is construed as in the nature of a termination or because the employer has expressly amended the plan to provide for full vesting at the time of conversion; and suppose, further, that the employer resorts to the precaution of obtaining the consent of all participants to the reformation of the pension plan. Do these circumstances, singly or together, make for constructive realization? The answer must still presumably be no. In a case where an employer dropped one pension plan in order to start a different one, with the consequence that all participants received an actual distribution of their accounts, but where the participants had previously signed an agreement with the employer to pay into the new pension trust all funds received from the old one, the Service has conceded that the employees did not realize taxable income. ${ }^{.8}$ The transaction was considered simply as "a transfer of funds from one such trust to another through the agency of the employees." No reason suggests a different result where the switch is from a pension plan to a profit-sharing plan.

The employer that has chosen the wrong kind of plan for its needs or abilities, or the employer whose needs have changed, would thus appear able to recast a pension plan into a profit-sharing plan, or vice versa, with a minimum of complications-in fact, without anything more than an amendment of the original trust. Of course, to effectuate such an amendment without submitting it to the Internal Revenue Service for requalification in accordance with the criteria applicable to pension or profit-sharing plans, as the case may be, would be foolhardy. Other incidental steps would also be necessary-for example, possibly a partial cancellation of insurance policies where a pension plan changes into a profit-sharing plan, since the Service's rules governing profit-sharing plans limit the premium for life insurance policies maintained by a profit-sharing trust to $50 \%$ of the contributions for employees. ${ }^{69}$

\section{Continuation of a Trust After Discontinuing Contributions}

When all other methods of accommodating the employer's obligations under its pension or profit-sharing plan to its current circumstances have failed, complete discontinuation of contributions may become necessary. The question has troubled many practitioners whether an employees' trust can be continued after contributions have been permanently discontinued. Several circumstances might give rise to this situation: the employer might be compelled by financial circumstances or personnel considerations to discontinue contributions; the employer coming out of a military build-up period may have laid off all but its stockholder-employees and may fear that continued contribu-

68. Rev. Rul. 55-368, 1955-1 Cum. Bull. 40.

69. See Rev. Rul. 54-51, 1954-1 Cum. Bull. 147. 
tions to a trust in which its stockholders are the only remaining participants will not be deductible; or the employer may have been liquidated and dissolved. In all of these cases, the trust would obviously benefit if it could be kept in existence as a qualified employees' trust, for any investments it makes would continue to enjoy tax shelter. Moreover, the participants could continue to defer the income represented by their trust shares.

The idea of keeping the trust in existence after the employer which gave it life has been dissolved presents the most intriguing possibility. The notion is only slightly more preposterous than the acquisition by the pension trust of control of the employer-corporation, a situation which is known to have occurred already in this country. In what is essentially the converse of the suggested case, the Service has ruled that a trust loses its qualification when there are no longer any employees covered by it. ${ }^{70}$ The ruling is based on the fact that the statutory requirement for qualification is predicated on the existence of a trust which is part of the plan of an employer for the benefit of its employees, to which the employer makes contributions for the purpose of distributing corpus or income to such employees, and which benefits such employees. A "plan completely lacking in covered employees" obviously does not satisfy these conditions for qualification, said the Service; no more so, it would seem, a plan completely lacking in an employer.

Of course, the situations may be distinguished : a trust without a beneficiary will be struck down as a matter of trust law, while private trusts whose grantors are not in existence are commonplace-for example, testamentary trusts created under a will. But the policy behind the special tax treatment of employees' trusts seems to rest upon a desire to encourage employers to make provision for retirement benefits for their employees. If the employer is defunct, such encouragement is impossible. Thus, the continuation of an employer-employee relationship throughout the existence of the trust would appear necessary for the trust to continue to enjoy its special tax advantages.

The situation is changed, however, when the corporate employer which was dissolved is succeeded by another corporation which employs the original personnel. Here, the original trust quite clearly can be taken over and continued by the successor, even after the original employer has gone out of existence. The successor need only assume the plan; although if the trust did not provide in its original form for the assumption of the plan by a successor corporation, some such amendment might be necessary before the dissolution of the original employer. Requalification of the trust would be advisable whenever a new corporation stands in the shoes of the "employer" under the plan. No reason appears to differentiate between various methods of acquiring the predecessor's business-whether by purchase, statutory merger or other corporate reorganization. Nor does it seem important that some of the predecessor's employees who were covered by the plan do not work for the successor.

70. Rev. Rul. 55-629, 1955-2 CuMr. Burl. 588. 
While the existence of an employer and employees appears to be essential to continuance of a trust, must contributions also be continued throughout the trust term? The Code provides that an employees' trust is qualified if "contributions are made to the trust" by the employer. ${ }^{71}$ To satisfy this condition, contributions need not be made currently. In Lincoln Electric, the employer made only a single contribution to the trust. ${ }^{72}$ And the Service has given tacit approval to the permanent discontinuance of contributions to a profit-sharing plan under which the directors had authority to discontinue contributions if they deemed it inadvisable or impossible for the corporation to continue to make them. ${ }^{73}$ Other provisions of the plan were to remain in effect, and the trust was to be continued in existence. The only requirement imposed by the Service was that all interests of participants vest fully at the time of discontinuance of contributions, lest discrimination become possible in favor of preferred categories of employees who would otherwise stand to benefit from forfeitures of the interests of other participants. Of course, this apparently liberal position by the Service is hard to reconcile with its requirement for a permanent plan calling for recurring contributions. However, as long as there have been recurring contributions for a period sufficient to refute any implication that the plan "from its inception was not a bona fide program for the exclusive benefit of employees in general," 44 the discontinuance of contributions should not of itself be prejudicial to the continuance of the trust.

The Service has also conceded that the trust can be continued when substantially all the employees once covered by the plan have severed their employment. As long as one employee is actually covered by the plan, the trust may be qualified, provided that it "is not operated as a means of siphoning profits to a shareholder-employee." 75 And the tax court has held that a plan which was terminated at a time when only one employee was covered was not disqualified, since that employee was not a stockholder, officer, supervisor or highly compensated person. ${ }^{76}$ In another case, however, the Service has ruled that where a plan was terminated after the cancellation of a war contract, at a time when the only persons covered by the plan were stockholder-employees and a bookkeeper, the plan lost its qualification retroactively, because an intention appeared to siphon off a substantial portion of the company's wartime profits for subsequent distribution primarily to stockholders. ${ }^{77}$

71. INT. Rev. CoDE of 1954, $\$ 401$ (a) (1).

72. 190 F.2d at 326.

73. Rev. Rul. 55-186, 1955-1 Cuar. Bulz. 39; Rev. Rul. 57-163, 1957 Int. Rev. Bull. No. 16 , at $30-31$.

74. U.S. Treas. Reg. $\$ 1.401-1$ (b) (2) (1956).

75. Rev. Rul. 55-81, 1955-1 Cum. Bull. 392; Rev. Rul. 57-163, 1957 INT. Rev. Butl. No. 16, at 22 .

76. Marjorie F. Birnie, $12 \mathrm{CCH}$ Tax Ct. Mem. 867 (1953).

77. Mim. 6136, 1947-1 Cuar. Bulı. 58. 
Where the trust is in danger of losing its qualification because of the lack of employees other than those in the favored categories, discontinuing further contributions does not seem a likely method for saving the qualification. The fact that the trust then exists primarily for the favored few is probably enough to disqualify it, although no further contributions are made thereafter. Termination of the plan and the trust before that point is reached is the best solution, to avoid possible retroactive disqualification and forfeiture of the special tax advantages accorded to distributions under qualified trusts. It should be borne in mind, however, that under the statute a distribution made upon the occasion of the termination of the trust but not associated with a severance of the distributee's employment is not eligible for capital gain treatment even though the trust continued qualified to the day of its termination.

Perhaps dissolution of the employer-company will be useful to save capital, gain treatment at termination of the plan, provided that this does not thrust upon the stockholders an unwanted capital gain upon the redemption of their stock; but even a dissolution would not be likely to produce a capital gain tax on the pension distributions if it is followed immediately by the reincorporation of the enterprise by the same interests. However, a sale of the enterprise to different interests will entitle the employees to capital gain upon the termination of the trust even though they are then employed en masse by the purchasing corporation. ${ }^{78}$ Alternatively, if the employer corporation is merged into another corporation, pursuant to a tax-free reorganization under the Internal Revenue Code, so as to effect a real change in the ownership of the business, the successor corporation can terminate its predecessor's pension or profit-sharing plan and distribute the benefits to participants at capital gain rates, without causing the stockholders of the predecessor corporation to realize any taxable gain upon the redemption of their stock. ${ }^{79}$

\section{CoNCLUSION}

A company need not shy away from the adoption of a profit-sharing or pension plan because of concern over the commitment it will have to assume upon initiating such a plan. A few of the techniques for accommodating such plans to the varying abilities of employers have been suggested. Other means doubtless exist or will be developed in time. Although methods for achieving some plasticity are at hand, employers should not, for this reason, be cavalier in the matter of contributions. The making of contributions only "at such times or in such amounts that the plan in operation discriminates" is still the sure road to disqualification.

78. Rev. Rul. 58-96, 1958 INT. Rev. Bull. No. 11, at 24; cf. Rev. Rul. 58-95, 1958 INT. REv. Burl. No. 11, at 21 (sale of employer's stock to successor corporation for cash).

79. Rev. Rul. 58-94, 1958 Int. Rev. Bull. No. 11, at 18; see Lurie, Pensions After Mergers and Spin-offs, 10 TAX L. Rev. 531, 532-34 (1955). 


\section{THE YALE LAW JOURNAL}

StepHen N. Shuldan

Editor-in-Chief

ROBERT T. BASSECHES

Alan J. Hruska

Comment Editors

\section{ROBERT L. BARD}

Thomas D. Barr

Frederick L. Bernstein

David P. Bicks

Norman A. Bikales

BenjaMIIN W. Boley

RICHARD A. BRADY

NewTON D. BRENNER

David Burres

Peter D. Caldiwell.

Laura M. Chapman

Sydney M. Cone, III

Paul H. DeCoster

Robert J. Del Tufo

ROBERT J. ENGELAIAN

ERNEST J. EtTlinger

Mitchel J. Ezer

Arthur Fleischer, Jr.

\author{
Milton P. DeVane \\ Article and Book \\ Review Editor
}

\section{William C. BASKIN, JR. Managing Editor}

SETh E. Frank

ThOMAS N. FromoCK

DAVID GoLDBERG

BURT W. GRIFFIN

Milton S. Gwirtzman

NerL S. HeCHT

REUBEN L. HEDLund

JACOB W. HELLER

JERoLd H. ISRAEL

Stephen J. Jelix

William A. Kass

N. Herschel KobLENz

J. D. LANIBERT

IRVING I. LESNICK

JoHN C. MCGuIRE

Frederick W. McNABb, JR.

JohN K. MCNULTy

RICHARD MARLIN

\author{
Gutdo Calabresi \\ W. L. F. FELSTINER \\ Note Editors
}

\author{
RICHARD M. MEYER \\ JERROLD L. MORGULAS \\ Hugh G. Moviton \\ Michael J. Nassau \\ Watter W. OberRett \\ Richard W. Pendeton, Jr. \\ Charles J. Prentiss \\ BURTON RaFFEL. \\ Richard Sexton \\ Barry Sidman \\ Douglas O. Smith, Jr. \\ LEWIS A. STERN \\ Colin C. TAIT \\ JOSEPE N. TAUBER \\ Stanley E. Tobin \\ Patricia W. Weingerg \\ T. CECIL WRAY, JR. \\ ALAN L. WURTZEI.
}

Marte McMahon

Busiress Secretary

\section{CONTRIBUTORS TO THIS ISSUE}

Hermann Mannheim. Hon. Director, Criminological Research Unit, London School of Economics and Political Science.

FREDERICK P. StoRke Professor of Law, University of Colorado School of Law.

Don W. Sears. Professor of Law, University of Colorado School of Law.

Alvin D. LurIE Member of the New York Bar. 